\title{
DISFARCES, ESCONDERIJOS E GEOSSIMBOLISMOS NA VENEZA AMERICANA: OS "CATIMBOLADOS" NO RECIFE (1937-1945)
}

FALLS, CUSHIONS AND "GEOSIMBOLYSMS" IN THE AMERICAN VENICE: THE "CATIMBOLADOS" IN THE RECIFE(19371945)

\section{RESUMO}

No regime de Estado Novo (1937-1945) no Brasil enalteceu-se o negro como elemento nacional. Contudo, frente à ameaça comunista, não se aceitara a formação de grupos sociais "diferentes" no Brasil. Em Pernambuco, o Interventor Agamenon Magalhães foi incisivo no combate às práticas afrorreligiosas, e, assim, aos xangôs da Catimbolândia, situados nos arredores do Recife, às margens do rio Beberibe, na divisa com Olinda. Neste período, a capital pernambucana mostravase um espaço disciplinar, imersa em reformas urbanas e na reeducação dos citadinos diante do novo, distanciando-se das marcas colonial-africanas de tempos passados. Desejava-se a materialização da Veneza Americana - branca, sã, católica e moderna. Malgrado a estrutura rígida de dominação, os negros dos terreiros não foram agentes passivos à repressão, buscaram assegurar suas casas e costumes fazendo uso de variadas estratégias de resistência, construindo suas territorialidades dentro e fora dos xangôs. Os "catimbolados" criaram múltiplos disfarces, esconderijos e geossimbolismos dentro dos terreiros e nos espaços públicos da Veneza Americana.

Palavras-chave: xangôs; territorialidades; Catimbolândia; Veneza Americana; Recife; Estado Novo.

\section{ABSTRACT}

In the New State regime (1937-1945) in Brazil, black people has been exalted as national element. However, in the face of the Communist threat, the formation of "different" social groups in Brazil has not been accepted. In Pernambuco, the Interventor Agamenon Magalhães was incisive in the fight against the Afroreligious practices, and thus the xangôs of Catimbolândia, located in the environs of Recife, on the riverside of the Beberibe river, in the border with Olinda. During this period, the capital of Pernambuco was a disciplinary space, immersed in the urban reforms and in the re-education of citizens in front of the new, distancing itself from the colonial-African marks of past times. It has the desire of the materialization of the American Venice - white, healthy, catholic and modern. Despite the rigid structure of domination, the black people of the terreiros were not passive agents to the repression, they tried to assure their houses and customs making use of varied strategies of resistance, constructing their territorialities inside and outside the xangôs. The "catimbolados" created multiple disguises, hiding places, and geosymbolisms within the terreiros and public spaces of American Venice.

Keywords: xangôs; territorialities; Catimbolândia; Recife; American Venice; New State.

\section{Bruno Maia Halley ${ }^{a}$}

${ }^{\text {a }}$ Universidade Federal do Rio Grande do Norte (UFRN), Natal, RN, Brasil

DOI: 10.12957/geouerj.2020.44404

Correpondência: bhalleype@hotmail.com

Recebido em: 4 ago. 2019

Aceito em: 27 mai.2020 


\section{CONSIDERAÇÕES INICIAIS}

No contexto do nacionalismo do Estado Novo (1937-1945) enaltecera-se o negro em sua origem africana como elemento da cultura brasileira. Contudo, não se aceitava a formação de grupos sociais "divergentes" ao regime de Getúlio Vargas. Dada à instabilidade político-social da época, temia-se a proliferação de "forças ameaçadoras", como o comunismo, com a repressão agindo contra organizações de esquerda, e também contra outras instituições e grupos étnico-religiosos, como anarquistas, protestantes, judeus, maçons, kardecistas e afrorreligiosos. Em Pernambuco, o Interventor Federal Agamenon Magalhães tornou-se um dos mais ortodoxos no combate aos xangôs, realizando uma profilaxia social contra as casas de culto através da ação sistemática da polícia. Os terreiros mais perseguidos foram os da cognominada Catimbolândia, reduto do povo de santo entre o Recife e Olinda, nos arredores do baixo rio Beberibe, atuais bairros do Arruda, Água Fria, Fundão, Encruzilhada, Campo Grande, Mangabeira e Beberibe. ${ }^{1}$

No entanto, os afrorreligiosos destes arrabaldes não foram agentes passivos frente à repressão. Criaram inúmeras estratégias de resistência como tentativas de garantia de suas práticas e territórios de culto. Durante o Estado Novo, a Catimbolândia confrontava-se ao desejo de construção da Veneza Americana, com o Recife imerso na modernização e higienização de suas ruas centrais, na erradicação dos mocambos e na reeducação dos habitantes diante do trabalho, da família e da pátria. A cidade mostrava-se um espaço disciplinar, com as autoridades e elites político-econômicas desejando a formação de um novo cidadão, branco, educado, católico e são, em substituição aos "africanos", "incultos e maltrapilhos". À luz deste contexto, o trabalho ora apresentado analisa a repressão do Estado Novo sobre os xangôs, destacando os meios de resistência dos "catimbolados" em suas várias territorialidades expressas em disfarces, esconderijos e geossimbolismos nos arredores do Beberibe, sobretudo durante o período noturno, quando os contrários da crença adormeciam na Veneza Americana.

\section{O Recife do Estado Novo: a Veneza Americana e a repressão aos xangôs}

Em 1937, a situação política do Brasil defrontava-se com um momento decisivo, com Getúlio Vargas subvertendo a ordem e tornando-se ditador. O regime do Estado Novo contava com a participação de forças políticas diversas, e divergentes entre si, mas todas direcionadas à restruturação do Estado. Os eventos de 1930, o golpe de 1937 e a eminente Segunda Guerra Mundial, fortaleceram a imagem do Estado Novo como a senda salvadora do Brasil, assumindo o desejo do novo e do moderno frente à ameaça comunista, dentro de um nacionalismo centralizador. As metas de Vargas assentavam-se no desenvolvimento econômico; na integração da sociedade à política nacional; na criação dos direitos sociais; e na consolidação do progresso e da ordem. Neste projeto, intelectuais clamaram uma nova identidade nacional, nascida do povo, em sua

\footnotetext{
${ }^{1}$ Sobre a existência da Catimbolândia entre o fim do século XIX e primeira metade do XX, vide o trabalho: HALLEY (2017).
} 
cultura popular. Enaltecia-se regionalismos, "brasilidades", valorizando o trabalhador brasileiro, inclusive o negro, enquanto raça componente da nação, em detrimento às ideias eugenistas de outrora (CAPELATO, 1998; CARONE, 1977; CAMPOS, 2001).

O regime enfatizava a doutrina social cristã na sociedade (LUSTOSA, 1991). A propaganda varguista expunha imagens religiosas junto à bandeira nacional, usando-as como projeto para tornar as massas acríticas, anticomunistas e anti-semitas (CAMPOS, 2001). De forma paralela, o controle das massas também se realizava com a caça aos culpados, em especial comunistas e integralistas, além de anarquistas, judeus, ciganos e japoneses. Em Pernambuco, nomeara-se o Interventor Federal Agamenon Magalhães, em substituição ao exgovernador Carlos de Lima Cavalcanti, acusado de associação ao comunismo. Agamenon construiu uma política reunindo oligarquias do Sertão e camadas populares do Recife que o apoiavam. Elencou como meta erradicar aquilo tido como "feio" e "atrasado", remanescente da República Velha. O Recife tornara-se, assim, um espaço de controle, calcado num projeto de remodelação urbanística e numa reeducação dos seus habitantes. A capital adentrava no projeto de restaurar a nação a partir da restauração das cidades brasileiras, imersas em zonas de pobreza. Justificavam-se as reformas urbanas como um benefício aos pobres, mais susceptíveis ao "mal do comunismo" (ALMEIDA, 2001).

Os moradores do Recife eram constantemente disciplinados, doutrinados às noções de ordem, higiene e trabalho. A higienização do centro intensificara-se, proibindo-se a circulação de ambulantes nas ruas e praças dos bairros do Recife, Santo Antônio, São José e Boa Vista. O terror policial expulsava engraxates, meretrizes, carregadores de fretes e vendedores de víveres da civilizada Veneza Americana. No bojo desta segregação, laços ideológicos com o mundo europeu foram estreitados, com os jornais aludindo a geografia anfíbia do Recife à cidade de Veneza. Também enalteciam a efervescência das inovações técnicas na cidade: luz elétrica, elevadores, cinema, automóveis, ônibus, telefone... A Veneza era festejada nos prédios de luxo, nos restaurantes, hotéis e na esquina do Café Lafayette. Os antigos sobrados, becos, pátios e igrejas, foram em parte substituídos por avenidas e arranha-céus, testemunhos da grandeza do regime para a memória da cidade. $^{2}$ O Recife expandia-se seguindo planos de urbanização, dentro do ímpeto modernizante da época.

Prefeito do Recife no Estado Novo, Novais Filho nomeara uma comissão pública que criou o Plano Definitivo de Reforma do Bairro de Santo Antônio, em 1938, cuja execução marcara-se pela abertura da Avenida 10 de novembro e construção da Praça da Independência. Houve o aterro de alagados e mangues, pavimentação de ruas, construção de prédios e pontes, extensão de iluminação e jardins inaugurados. Em

\footnotetext{
20 “espetáculo das demolições” no Recife já se verificava desde a reforma do bairro portuário no início do século XX. Entre 19221926, a gestão de Sérgio Loreto provocara uma série de intervenções. Houve a reformulação dos serviços de saúde, afora a construção de casas populares, a erradicação de mocambos, aterros de mangues, a ampliação dos serviços de luz elétrica, e a abertura de ruas e avenidas. "Até maio de 1929, já haviam sido demolidos 32 prédios no bairro de Santo Antônio" (GOMINHO, 1997, p. 55)
} 
1943, iniciara-se a abertura da Av. Dantas Barreto, “sangrando" ruas de Santo Antônio. O regime também articulou ampla campanha contra os mocambos, os quais proliferaram-se desde o fim da escravidão e a chegada de migrantes ao Recife. Os mocambeiros residiam nos alagados e mangues dos rios Capibaribe e Beberibe, onde encontravam água e alimentos da maré: crustáceos, peixes e caranguejos. Para os retirantes, pescadores, operários, lavadeiras e meretrizes, o mangue constituía-se num “camaradão", no dizer de Josué de Castro (1968, p. 26). Afora fornecer a matéria-prima ao mocambo, dava "o pão de cada dia": o caranguejo. "São cem mil indivíduos, cem mil cidadãos feitos de carne de caranguejo. O que o organismo rejeita, volta como detrito, para a lama do mangue, para virar caranguejo outra vez" (CASTRO, 1968, p. 26). Neste ciclo, as famílias sobreviviam, abrigando-se em “[...] cumbucas negras boiando nas águas. [...] verdadeira senzala remanescente fracionada em torno às Casas Grandes da Veneza Americana" (CASTRO, 1968, p. 17).

Na década de 1930, a “Mucambópolis" (MELO, 1940) já totalizava metade das habitações do Recife. Entre 1931-32, a cidade abrigava 23.869 habitações "normais", e mais 23.210 mocambos, com a população estimada em 446.178 almas. Em 1939, já ultrapassava meio milhão de pessoas (550.389) (CARONE, 1977). O Recife inchava-se, com a expansão da Veneza pelos bairros da Boa Vista, Derby, Espinheiro, Casa Forte e Dois Irmãos. A Mucambópolis situava-se nos alagados, expandindo-se também pelos sítios junto às ocupações da Cidade-Veneza. Os casebres espalhavam-se pelas freguesias de Afogados, Várzea, Poço da Panela, Graças e Beberibe, ora aforando sítios legais ou terrenos de posseiros, ora invadindo os mangues e alagados (Figura 01). Quando da maior necessidade deslocavam-se, em razão das ameaças policiais, das inundações, do aumento do aluguel, e da oportunidade de trabalho. Neste processo, muitos terreiros fixados em mocambos saíram dos bairros centrais rumos aos arredores do Beberibe ${ }^{3}$ - a Catimbolândia. Em Campo Grande, o Sítio do Marçal fora rapidamente ocupado por mocambeiros (RIBEIRO, 1936), e decerto por vários xangôs, como os de Maria Oyá, de José da Costa (Noberto), o de mãe Lídia Alves, e o de pai José do Café.

Na ótica do regime, da elite político-econômica e da imprensa local, a miséria da cidade relacionava-se à existência do mocambo. As choças de pau, barro e palha de coqueiros consistiam em "heranças africanas degradantes", sujeitas ao "contágio físico e espiritual”, fomentadora da "pobreza", "infelicidade" e "crimes".

\footnotetext{
${ }^{3}$ Entre os séculos XIX e XX, dentro das transformações ocorridas na vida urbana, política e econômica do Brasil com a Abolição da Escravatura e o advento da República, as nações abrigadas em xangôs no Recife foram se refugiando nos arredores, tanto as vindas do centro urbano, como aquelas vindas de outros espaços nordestinos. A maioria concentrara-se nos arrabaldes do Beberibe, particularmente às margens do afluente Água Fria, nos povoados do Arruda, Água Fria, Arruda, Fundão, Encruzilhada, Campo Grande, entre outros. Os xangôs de origem jêje-nagô, xambá, xanhá, savalu e calabar, procedentes de Angola, Congo e Costa da Mina, foram erguendo seus mocambos nestes espaços, em meio aos sítios frutíferos, alagados, mangues, matas e morros da geografia local. Se no Rio de Janeiro, os povos de santo estiveram situados na Pequena África, entre o século XIX e XX, às margens da Baía de Guanabara, na zona portuária da Gamboa e Saúde; e se em Salvador, os candomblés do povo nagô concentraram-se no Recôncavo Baiano, em Cachoeira (São Félix), em meados do século XIX; no Recife, por sua vez, os terreiros foram se fixando nas terras drenadas pelo Beberibe, na divisa com Olinda. Desprovida de uma grande reentrância natural, como a Guanabara ou o Recôncavo, os xangôs do Recife refugiaram-se nas terras do Beberibe, historicamente um espaço periférico de longo envolvimento com os negros desde a Colônia e o Império (contando inclusive com o Quilombo do Malunguinho às suas margens no século XIX). O rio Capibaribe, contudo, ligara-se aos senhores brancos das Casas Grandes, dedicados ao plantio de açúcar, em cujos engenhos havia senzalas repletas de cativos (HALLEY, 2017).
} 
“Portanto, identificava-se na erradicação dos casebres a emergência da felicidade, da alegria, da higiene, do trabalho e da ordem" (ALMEIDA, 2001, p. 129). Agamenon esforçava-se em eliminar os casebres substituindoos por vilas operárias. Através da Liga Social Contra os Mocambos concedia as casas, constituindo-se um instrumento de poder do Estado para higienização da cidade e para a doutrinação das famílias frente ao trabalho e às obrigações com Deus e à Pátria. Além das vilas, foram criados os Centros Educativos Operários, com oferta de cursos profissionalizantes, além de cobertura médica. A Igreja colaborava com o Estado através do Grupo de Ação Social e dos Círculos Operários Católicos, oferecendo instruções técnicas, afora assistência médica e jurídica. O Estado e a Igreja trabalharam juntos, estando a favor da família e do lar e contra o "comunismo", a "imoralidade" e a "irreligião", como os xangôs (GOMINHO, 1997).

Figura 1. Crianças mocambeiras com os pés na lama, Recife, década de 1940.

A foto de Berzin capta a estreita ligação das populações pobres com os mangues e alagados do Recife, residindo em mocambos e sobrevivendo com as ofertas trazidas pelas águas lamacentas da maré. Foto Alexandre Berzin, década de 1940. Fonte: Acervo do Museu da Cidade do Recife. Tombo 00295.

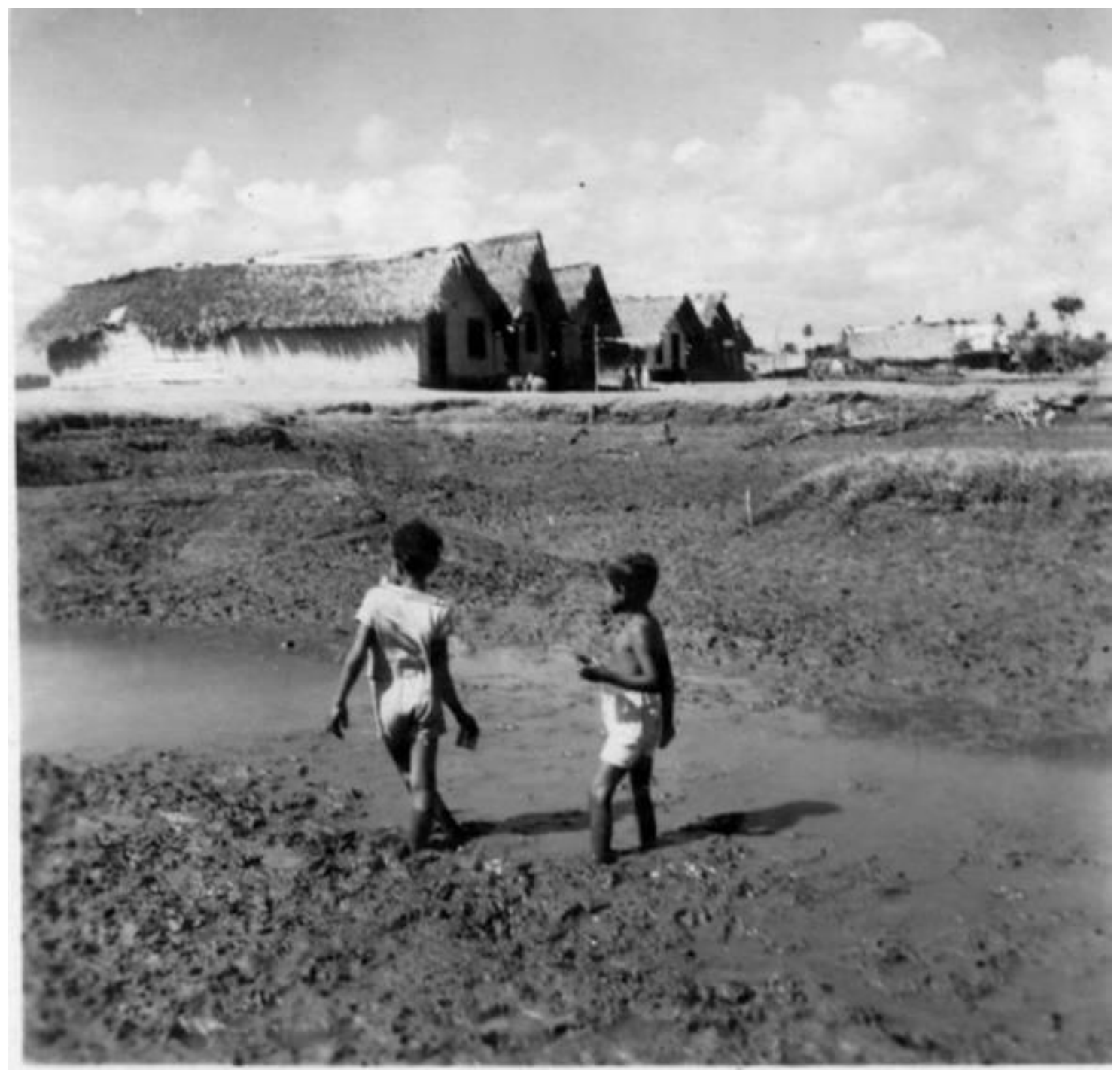


Embora o nacionalismo da época enaltecesse o trabalhador negro, destacando a raça como componente da nação e elogiando o ecletismo étnico do brasileiro em detrimento às noções de eugenia e branqueamento de outrora ${ }^{4}$, o regime não aceitava a formação de grupos "distintos-divergentes" aos padrões de comportamento adotados pelo varguismo. O grande temor era o comunismo, sobretudo entre os mais pobres, imersos em "primitivas" organizações. Eleitos como perigosos, a repressão concentrava-se nas organizações de esquerda, mas também nos grupos religiosos, como os maçons, judeus, protestantes, kardecistas e afrorreligiosos. ${ }^{5}$ Em Pernambuco, os xangôs sofreram um ataque violento, com Agamenon exigindo medidas de profilaxia moral e social contra as casas de culto. Os ideais nacionalistas sobre a tradição afro-brasileira não sensibilizaram o racista Agamenon (ALMEIDA, 2001). Seminarista na mocidade, o interventor recebia o apoio irrestrito dos cristãos contra os xangôs. Parte do seu secretariado e polícia era formado por Congregados Marianos - os “Capangas de Deus”. A Igreja, por sua vez, auxiliava o Estado, criando discursos negativos aos xangôs, associando termos demoníacos aos cultos. Nesta cruzada havia também uma segregação entre as religiões mediúnicas, com kardecistas promovendo um espiritismo científico frente às "crendices populares" dos terreiros. Faziam a distinção entre "alto" e "baixo" espiritismo, buscando através disto, maior aceitação e isenções de taxas para suas sedes (COSTA, 2009; QUEIROZ, 1999).

Outra forma de desqualificação dos xangôs era realizada por jornalistas, ao publicar as prisões dos filhos de santo rotulando-os de criminosos, somente por não cultuarem a religião "oficial" do Estado. Pertencente à Agamenon, a Folha da Manhã colaborava com o regime. Além de reproduzir seus valores e atos repressivos, trabalhava para exclusão do povo de santo, denunciando focos de "catimbós" na Veneza Americana. Pouco a pouco desvelava-se os arredores-esconderijos do Beberibe ${ }^{6}$, cujas casas eram chamadas negativamente de "catimbós", "xangôs", centros de "baixo espiritismo", "degradação", "feitiçaria", e da "falsa medicina". A expressão "catimbó" fora uma das mais frequentes. ${ }^{7}$ Daí aqui se chamar Catimbolândia a reunião dos xangôs do rio Beberibe ${ }^{8}$, alvo maior das perseguições étnico-religiosas no Recife. A repressão policial invadia, prendia

\footnotetext{
4 Influenciados pelos estudos eugenistas de Nina Rodrigues e Arthur Ramos, médicos-psiquiatras do Serviço de Higiene Mental de Pernambuco, liderados por Ulysses Pernambucano, realizaram um "controle cientifico-territorial" sobre os terreiros do Recife, entre os anos de 1932-37, em especial nos xangôs da Catimbolândia. A equipe considerava o negro "inferior biologicamente", sujeito a "debilidades mentais" quando expostos aos seus "espaços doentios", os xangôs, que deviam ser controlados (HALLEY, 2017).

${ }^{5}$ Mesmo entusiastas da política de Vargas, os adeptos da Umbanda sofreram perseguição pelos setores encarregados pela Segurança Nacional. Difundida na cidade do Rio de Janeiro, essa "religião brasileira" baseara-se na junção das três matrizes culturais formadoras do Brasil, sendo composta por kardecistas, acadêmicos, comerciantes, servidores públicos e militares (BROWN, 1986). Em contrapartida, federações foram criadas para proteção das religiões afro-brasileiras, conformando-se estruturas de patronato apoiadas pelas classes dominante e média (CAMPOS, 2001).

${ }^{6}$ A expressão "arredores-esconderijos" construída para os arrabaldes da Catimbolândia, drenados pelo rio Beberibe, alude à criação de Sidney Chalhoub (1998), "cidade-esconderijo", termo cunhado para designar a imensa população negra e mestiça da Corte do Rio de Janeiro das últimas décadas da escravidão.

${ }^{7}$ Em pesquisa realizada no Arquivo Público de Pernambuco, a historiadora Martha Rosa de Queiroz (1999) encontrou em documentos de 1926 a 1937, a maior frequência da terminologia "catimbó" utilizada pelos órgãos do Estado, e também entre os jornalistas para denominar as religiões afro-brasileiras no Recife. Depois de "xangozeiros", "catimbozeiros" era o termo mais popular para rotular os afrorreligiosos. ${ }^{8}$ Em pesquisa de doutorado foram contabilizados 35 terreiros na Catimbolândia, entre 1930-40 (HALLEY, 2017). O nome Catimbolândia foi primeiramente utilizado pela historiadora Isabel Guillen (2007), em nota sobre a forte presença de terreiros na zona do Beberibe. Tomou-se emprestado esse cognome, como uma representação espacial destes povos de santo, um território de resistência étnico-religioso no contexto da Veneza Americana.
} 
religiosos, fechava casas e confiscava objetos. ${ }^{9}$ Em 1938, uma portaria fora baixada oficializando a caça aos "centros bárbaros", com o Diário da Tarde estampando a seguinte matéria: "Em repressão ao baixo espiritismo" - "Feliz deligencia fez uma batida no Centro de Adoração dos Reis Magos, localizado em Beberibe e dirigido pela catimboseira Caetana de Andrade encontrando-a em plena sessão". ${ }^{810}$ Outras casas da Catimbolândia invadidas foram do pai Arthur Rosendo, de Água Fria, da mãe Maria Oyá. e dos pais José do Café e José do Casquete, de Campo Grande (GUERRA, 2010).

Em meio à essas invasões, os jornais enalteciam a luta contra os "vilões" da cidade: "Contra o baixo espiritismo". 11 "Campanha contra catimbozeiros". ${ }^{12}$ "Contra o "espiritismo e a falsa medicina". ${ }^{13}$ Malgrado a repressão, os negros não foram agentes passivos. Inúmeros atos de resistência foram registrados, revelando as estratégias dos xangôs frente às tentativas de aniquilar suas práticas e espaços de culto. Chamava atenção a criatividade das táticas, especialmente na Catimbolândia, cujos terreiros configuravam verdadeiros "territórios-santuários" (BONNENMAISON, 2012), imersos em distintas formas de territorialidades, estendendo-se aos espaços das matas, árvores, águas, morros, rochedos e encruzilhadas. Tais estratégias estão geografadas no pormenor Tramas negras dos xangôs na Catimbolândia - arredores do Beberibe (décadas de 1930-1950) (Figura 02), com destaque paras as territorialidades e geossimbolismos dos xangôs no Estado Novo, e década posterior.

Rememoram-se essas estratégias negras como atos de antidisciplina, mecanismos baseados nos costumes e tradição em face às táticas de controle da Veneza Americana, baseada em técnicas ditas científicas, forjadores da modernidade. A antidisciplina trata-se de uma recíproca de Michel De Certeau (2005) à noção de disciplina de Michel Foucault (1993). A noção de Foucault analisa os procedimentos, instrumentos e estratégias inerentes à sociedade disciplinar moderna. Por outro lado, De Certeau afirma existir outra infinidade de práticas e saberes cotidianos e heterogêneos contrários às estratégias do poder disciplinar. Apreende-se as táticas infinitas, inventivas e escondidas, retratadas por De Certeau, a partir das resistências criadas pelos povos da Catimbolândia frente às normas de controle Veneza Americana.

\footnotetext{
${ }^{9}$ Os objetos apreendidos foram encaminhados ao Museu da Directoria de Hygiene Mental. Em 1940, o Museu do Estado de Pernambuco passou a abrigar o material, "resguardando" a memória dos terreiros "um testemunho do xangô pernambucano", não mais existente no Recife. In: MUSEU DO ESTADO DE PERNAMBUCO. Coleção culto afro-brasileiro - um testemunho do xangô pernambucano. Recife, 1983. ${ }^{8}$ EM REPRESÃO AO BAIXO ESPIRITISMO. Uma visita da polícia ao "Centro dos Reis Magos". O Fechamento do Círculo Pantheísta. Diário da Tarde, Recife, 08 de fevereiro de 1938.

10 EM REPRESÃO AO BAIXO ESPIRITISMO. Uma visita da polícia ao "Centro dos Reis Magos". O Fechamento do Círculo Pantheísta. Diário da Tarde, Recife, 08 de fevereiro de 1938.

${ }^{11}$ Folha da Manhã, Recife, 08 de maio. 1938. p. 08. Edição Matutina.

12 Folha da Manhã, Recife, 09 de julho. 1938. p. 08. Edição Matutina.

${ }^{13}$ Folha da Manhã, Recife, 17 de agosto. 1938. p. 12. Edição Matutina.
} 
Figura 2. Tramas negras dos xangôs na Catimbolândia - os arredores do Beberibe (décadas de 1930-1950).

As estratégias estão representadas nas seguintes territorialidades: deslocamentos dos xangôs; peregrinações ao Monte Giz e aos cursos d'água; a devoção às "árvores sagradas"; e os sincretismos religiosos (a capela, procissão da Bandeira de Alairá, o toque de lbeji - Festa Cosme e Damião, e os cruzamentos suburbanos). Também estão representados os terreiros invadidos pela polícia durante o Estado Novo, e a reinauguração do Xambá no Portão do Gelo, em 1951. Utilizou-se o pormenor da Planta da Cidade do Recife e Seus Arredores - 1876, de F. H. Carls, sem a pretensão de detalhar a ocupação do baixo Beberibe entre os anos de 1930-1950, mas apenas como uma forma de ilustrar a posição dos xangôs e de suas práticas dentro da Catimbolândia. Desenho: Autor (2017). Colaboração: André Pereira Marinho.

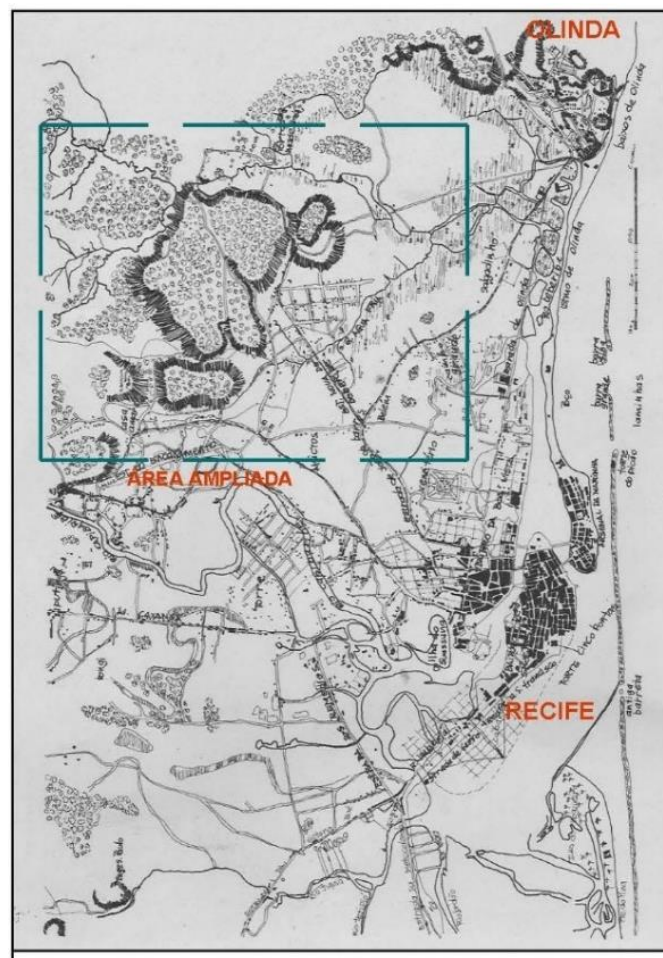

LEGENDA ÁREA AMPLIADA:

- ESTRADAS COM TRILHOS DE

SELÉTRICO

- ESTRADAS CARROÇÁVEIS

- RIOSE RIACHOS

TRAÇOS DO RELEVO

TERREIROS

----- DESLOCAMENTOS

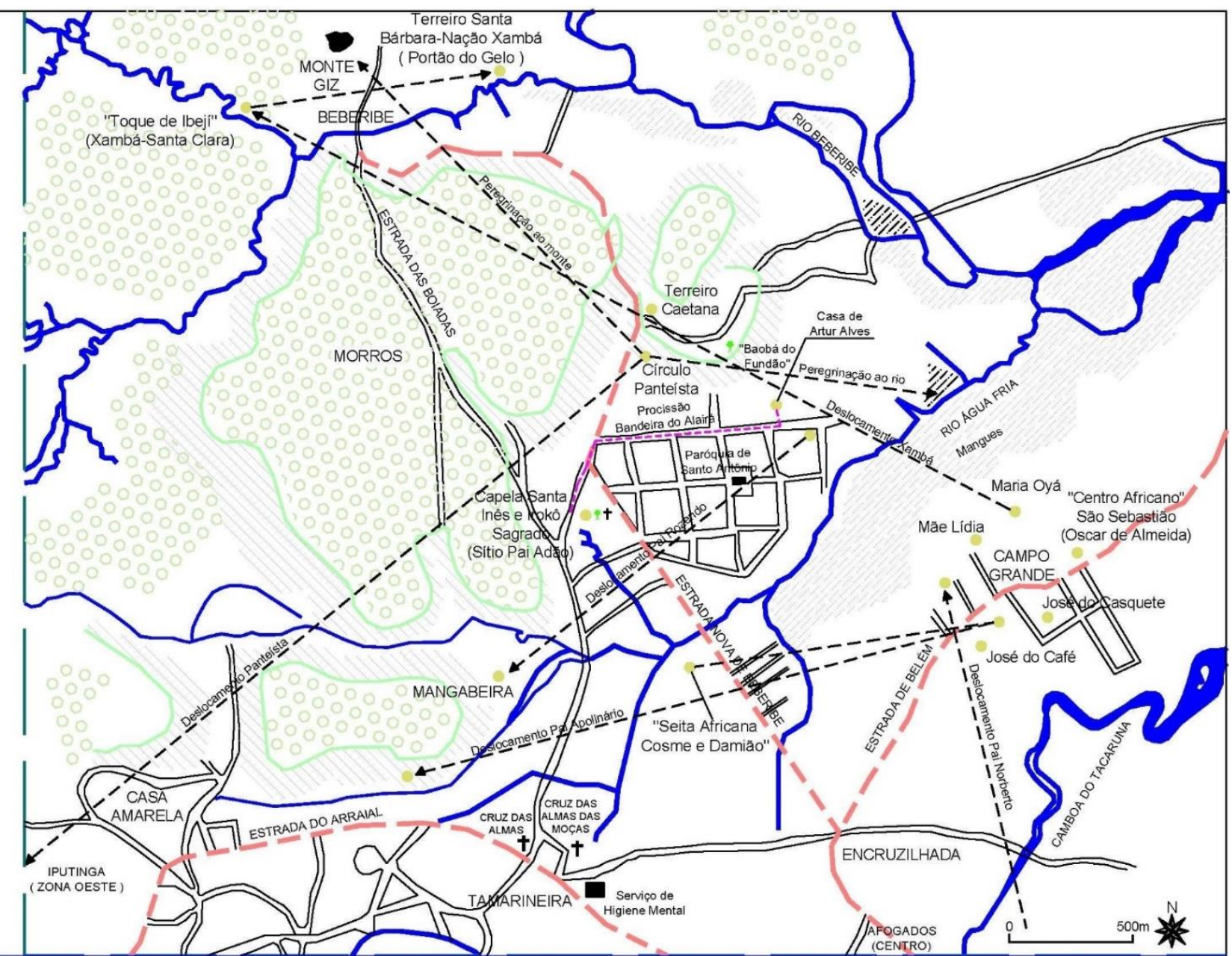


Rememoram-se essas estratégias negras como atos de antidisciplina, mecanismos baseados nos costumes e tradição em face às táticas de controle da Veneza Americana, baseada em técnicas ditas científicas, forjadores da modernidade. A antidisciplina trata-se de uma recíproca de Michel De Certeau (2005) à noção de disciplina de Michel Foucault (1993). A noção de Foucault analisa os procedimentos, instrumentos e estratégias inerentes à sociedade disciplinar moderna. Por outro lado, De Certeau afirma existir outra infinidade de práticas e saberes cotidianos e heterogêneos contrários às estratégias do poder disciplinar. Apreende-se as táticas infinitas, inventivas e escondidas, retratadas por De Certeau, a partir das resistências criadas pelos povos da Catimbolândia frente às normas de controle Veneza Americana.

\section{Disfarces, esconderijos e geossimbolismos: as tramas da Catimbolândia}

As tramas de resistência dos xangôs manifestaram sob diversas formas e ocasiões. Valente (1955) estudou o sincretismo religioso como uma destas estratégias, onde os negros recebiam a religião católica como um anteparo para disfarçar seus rituais. Na escravidão, a separação entre negros e brancos nunca excluíra o intercâmbio, pelo contrário, engendrara assimilações. Na Catimbolândia, resistência e assimilação eram indissociáveis. Os xangôs realizavam rituais com eguns, pretos-velhos, encantados, exus caboclos e orixás que eram assimilados às santidades branco-católicas analogicamente, através de São Jorge, Santa Bárbara, São Sebastião, entre outros. Os nomes das casas revelavam esse sincretismo, expressas em santidades de resistência, sacrifício e guerra, a exemplo do Terreiro de Santa Bárbara e do Centro Africano São Sebastião.

Na memória dos xangôs, o sincretismo também ocorria de forma mais específica quando dos toques. Os rituais eram realizados nas festas de aniversário, com os orixás camuflando-se por trás dos santos e liturgias católicas. Mãe Biu usava-se desta tática para burlar a repressão. Em Campo Grande, o aniversário de sua filha Cecinha comemorava-se com o Toque de Ibeji (Figura 03), camuflado em Festa de Cosme e Damião (COSTA, 2009). No Sítio de Pai Adão ainda existe a Capela de Santa Inês, em arquitetura católica, cujo nome alude à fundadora do terreiro. Entre 1930-40, casamentos eram realizados nesta capela, buscando legitimar a casa frente ao regime, e à sociedade em si, além de expandir seu mercado de almas, sobre o qual dependia economicamente. ${ }^{14}$ Ao assumir a liderança feminina do Sítio, em 1936, Joana Baptista introduzira a festa de São João, santo católico sincretizado com o orixá Xangô. Como tática frente ao autoritarismo, o velho chalé

\footnotetext{
14 Segundo Walfrido José da Silva, ogã mais antigo do terreiro e sobrinho de Pai Adão, quem construiu a capela foi Inês Joaquina Costa. "Foi ela quem fez a capela, tudo isto quem fez foi ela. Isto aqui é uma capela particular de santos. De santos da igreja católica. Aqui não só adora os santos africanos não, aqui é exclusivamente para estes da capela. Na época em que eu era menino, tinha casamento...". Entrevista concedida em 15 de janeiro de 2010, quando Walfrido tinha 95 anos de vida.
} 
do Sítio se enfeitava na véspera de São João, ocorrendo a procissão Acorda Povo ou Bandeira de Alairá pelas ruas de Água Fria. O cortejo ocorria pela madrugada, quando o controle policial era menor. ${ }^{15}$

Em face à repressão estadonovista, os adeptos dos terreiros colocavam em prática outro disfarce para a manutenção de suas casas. Registravam-se como centros kardecistas ou agremiações de carnaval, alvos menos perseguidos pelas autoridades. Os relatos das camuflagens eram comuns nos jornais: "Muitos macumbeiros, cartomantes, disfarçados de espíritas tentam se instalar no Recife. A Delegacia e Capturas não os deixou em paz". ${ }^{16} \mathrm{O}$ disfarce ficava evidente nos pseudônimos das casas, como o "Centro Espírita Caridade e Amor em Jesus Cristo"17. Quando não se camuflavam, deslocavam-se territorialmente. Saíam de uma rua a outra, ou de um arrabalde a outro do Beberibe. Pai Apolinário saiu da Encruzilhada para Campo Grande, e depois, para Casa Amarela (VALENTE, 1955). Noberto deslocara-se de Afogados para Campo Grande. Rosendo saiu de Água Fria para a Mangabeira. E Mãe Biu saiu de Campo Grande para Santa Clara, e, depois, para Beberibe. Nestas mudanças, a estratégia perpassara a espessura do território, que tornara-se relativamente móvel dentro de uma dimensão físico-material (HAESBAERT, 2007).

Mesmo instável, a conquista de um chão próprio representava uma articulação político-social do povo de santo. A partir de um território, os "catimbolados" demarcavam os espaços públicos como extensões de seus xangôs, locais de visibilidade e transmissão da cultura afro-brasileira para gerações subsequentes. Contudo, as ruas do Recife eram controladas pelos agentes do Estado Novo, como por apoiadores do regime. Diante desta fiscalização, os negros realizavam sigilosamente suas práticas, e sempre na calada da noite. Os ebós tinham uma ação protetora invisível frente às ameaças de tiro, faca, "mau-olhado", doenças e ações policiais. À noite, os crédulos "fechavam o corpo" na beira de rios e córregos, nas encruzilhadas, árvores sagradas, tufos de matas e ruas, ressignificando os espaços enquanto territórios do sagrado. Naquela época era comum nas cercanias do Recife colocar uma cruz e uma caixa no entroncamento de estradas para doações à missa das almas. Próximo ao Sítio de Pai Adão havia as Cruz das Almas e Cruz das Almas das Moças. O próprio Pai Adão depositava seus ebós nestes cruzamentos (FERNANDES, 1937). Afora isto, simpatias da sorte eram feitas para Exu, "o dono das estradas", rompendo publicamente com a invisibilidade das crenças na cidade. $\mathrm{O}$ Jornal do Pequeno estigmatizava as práticas como "Aberrações da Crendice Popular" ainda presentes na Veneza Americana. ${ }^{18}$

\footnotetext{
15 Vide: BANDEIRA DO SÍTIO. Roberto Benjamin. Jornal da Cidade. Recife. 03 a 09 de junho de 1976.

${ }^{16}$ A “MACUMBA" A SERVIÇO DO FUTEBOL. Folha da Manhã, Recife, 31 de julho. 1944, p. 4. Edição Matutina.

17 O CENTRO ESPÍRITA CARIDADE E AMOR EM JESUS CRISTO TRANSFORMADO EM SÊDE DE “MACUMBAS" DESENFREADAS E DELIRANTES - AS EXTRANHAS RECEITAS DOS “ESPÍRITOS” - ETC. Diário da Tarde, Recife, 12 de abril de 1934.

18 "É assim que indivíduos impacientes pela demora da sorte ou desesperançadas dos sonhos, das adivinhações e das tabelas, entregam-se a actos que são verdadeiras bruxaria, ou mesmo baixa magia negra. In: AS ABERRAÇÕES DA CRENDICE POPULAR. Jornal do Pequeno. Recife: 20 de agosto de 1931.
} 
A sacralização de geografias também existia entre os panteístas do Círculo Deus e a Verdade, do Prof. José Amaro, com peregrinações de adoração à natureza até os rochedos do Monte do Giz, em Águas Compridas, Olinda. As mulheres realizavam cerimônias propiciatórias ao longo dos rios, como o Beberibe e Água Fria, mas também nas "águas vivas" de cascatas do interior nordestino (LIMA, 1937). Incomodado com a devoção panteísta, o Estado Novo intervira no culto do Círculo, atingindo também o xangô da mãe Maria Gorda. ${ }^{19}$ Mesmo coagidos, os membros das casas não se deram por vencidos, passaram a realizar suas crenças tarde da noite ou em geografias mais distantes (FERNANDES, 1937). Passado o Estado Novo, os panteístas transferiram sua sede para a Iputinga, mesmo após a redemocratização promulgada pela Constituição de 1946. Ao deixarem os arredores do Beberibe, ainda fizeram uso de suas estratégias de aceitação. Nas ocasiões dos desfiles públicos, externavam o sentimento patriótico da época, expondo a bandeira nacional pelas ruas da Iputinga (LIMA, 1937). O xambá usava a mesma tática (e ainda usa), exibindo o lábaro no teto do salão de toque, em Beberibe.

Figura 3. Terreiro de Santa Bárbara - Nação Xambá, em 1948, Santa Clara. Gêmeos homenageando os santos Cosme e Damião, sincretizados em homenagem ao orixá africano Ibeji. Vide também os tambores e outros "filhos de santo" na entrada do terreiro de Mãe Biu. Foto de Pierre Verger, setembro de 1948. Fonte: Foto Pierre Verger@Fundação Pierre Verger. Tombo 36039.

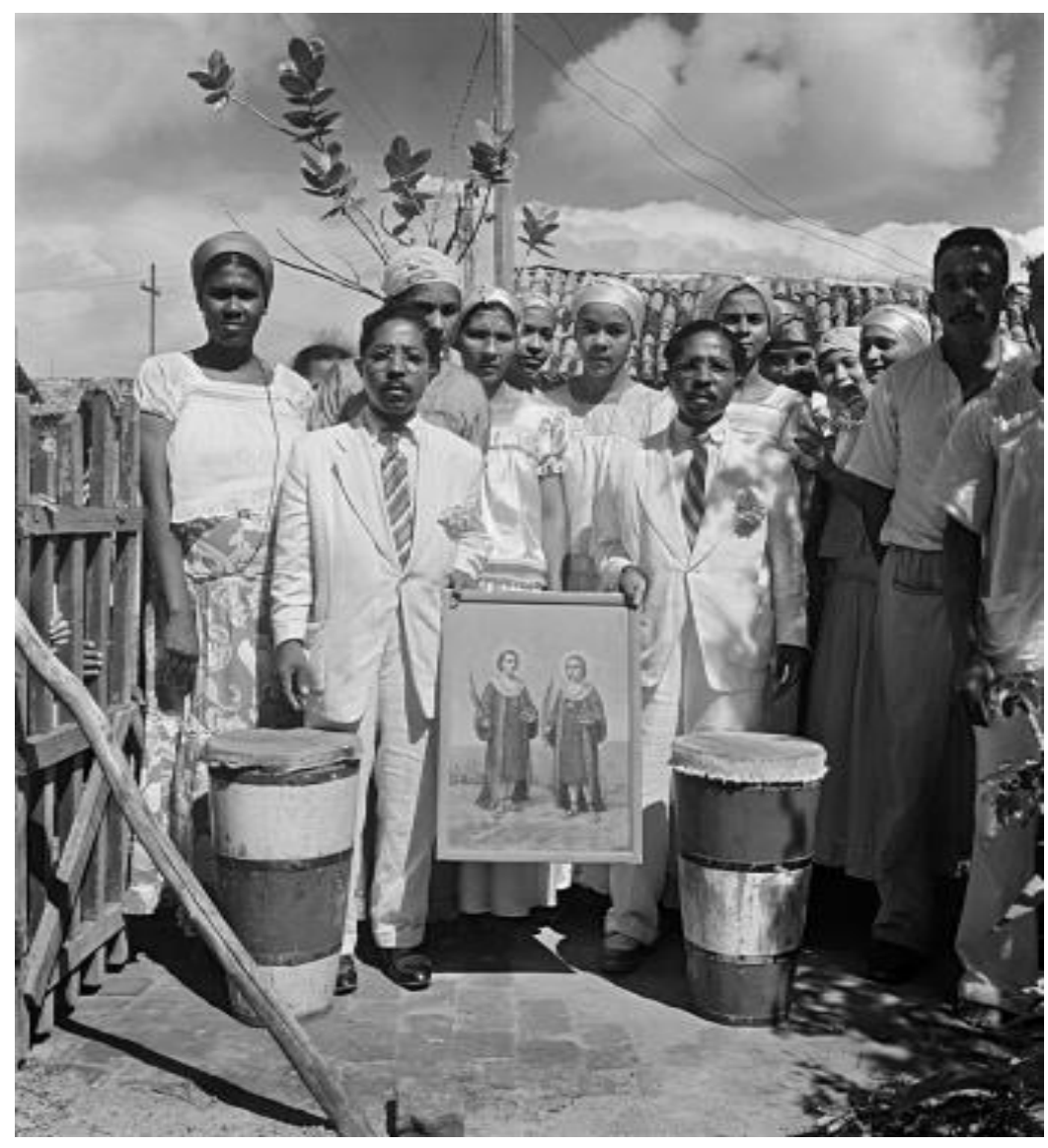

19 "Cahiu do "altar" o ultimo "orixá" - O FUNDÃO antigamente foi zona perigosa. Serviu por muito tempo de campo de acção as doutrinas extravagantes. O "xangô", o baixo espiritismo, os templos de adoração á natureza, tiveram no fundão essa época de fastígio. Havia o celebre "xangô" de "Maria Gorda", que encheu o subúrbio de superstições de lendas..." In: CAHIU DO "ALTAR" O ULTIMO “ORIXÁ". Folha da Manhã. Recife, 15 abr. 1939. p. 8. Edição das 16 horas. 
Afora as territorialidades construídas em torno das encruzilhadas, montes rochosos e na beira dos rios, os xangôs estabeleceram uma identidade junto às árvores sagradas - baobás e irokôs. Segundo Freyre (1968), os terreiros mais ortodoxos possuíam uma gameleira. Ritualizar a árvore conferia uma tradição africana trazida por escravos para o Brasil. Além de simbolizar ancestralidade com a terra-mater, e com os espíritos protetores, também representava força e resistência frente aos inimigos da crença. As árvores situavam-se dentro e fora dos terreiros, reafirmando as identidades das nações também nos espaços públicos, em confronto com a realidade do outro. Pai Anselmo realizava toada em devoção ao Irokô, mas quando indagado sobre a existência de alguma espécie nas redondezas, o mesmo negava (FERNANDES, 1937). Temia ações contra um baobá. Na Catimbolândia, as formas de resistência eram amiúde mascaradas, atestando a premissa: “o ideal do poder é jogar exclusivamente com símbolos" (RAFFESTIN, 1993, p. 58), ou geossímbolos, em se tratando dos xangôs do rio Beberibe.

No dizer de Bonnemaison, “[...] um geossímbolo pode ser definido como um lugar, um itinerário, uma extensão, que por razões religiosas, políticas ou culturais, aos olhos de certas pessoas e grupos étnicos, assume uma dimensão simbólica que os fortalece em sua identidade" (BONNEMAISON, 2012, p. 292). Os terreiros da Catimbolândia constituíam "territórios geossimbólicos", onde tudo neles contido possuía um valor simbólico para as comunidades religiosas - árvores, água, terra e construções. A casa de Adão possuía um sítio esplêndido, com gameleira sagrada, na entrada, e irokô, no fundo, além de uma cacimba à Oxumo. Nas árvores havia sacrifícios e cultos aos eguns (FERNANDES, 1937).

Os "paus encantados" também serviam de esconderijo quando das invasões policiais. A ialorixá Joana Baptista (Figura 04) "pendurava os santos no Irokô", recorda a filha de santo Iraci Vilela, a "Beleza". ${ }^{20}$ Quando não ocultava no Irokô, Joana escondia os orixás nos esconderijos da geografia local. Alguns corriam pelos becos e vielas, outros subiam o morro pela Ladeira de Pedra, em Água Fria, carregando os objetos até as casas de parceiros de resistência. "Agamenon fez ela (mãe Joana) carregar os santos lá para o morro, levar Yemanjá de noite lá pro morro, para ele não carregar", rememora Beleza. ${ }^{21}$ Na madrugada também existia o "xangô rezado baixo", com os toques silenciados e as toadas sussurradas para não despertar os contrários da crença. Assim, a Catimbolândia mantinha-se acordada enquanto adormecia a Veneza Americana. ${ }^{22}$

\footnotetext{
20 “Ela (Joana), como era muito influente, foi avisada a tempo e escondeu todos os santos na casa de amigos. Até um Ogum, ela escondeu em cima do Irokô, que acabou entrando no tronco da árvore, e ninguém conseguiu tirar. Portanto, do Sítio mesmo, a polícia não levou nada. Ela colocou tudo de mentira dentro do quarto do santo e foi isso que eles levaram". In: CAMPOS, Z. D. P. “Perseguida por Agamenon Magalhães: marcas de memória de uma mãe-de-santo pernambucana”. In: Revista SymposiuM. Ano 3, Número Especial, dez. 1999, p. 65-70.

${ }^{21}$ In: CAMPOS, Z. D. P. "Perseguida por Agamenon Magalhães: marcas de memória de uma mãe-de-santo pernambucana”. In: Revista SymposiuM. Ano 3, Número Especial, dez. 1999, p. 65-70.

22 Vide matéria do Diário de Pernambuco contra os xangôs: “[...] essa campanha recrudesceu depois que a delegacia se certificou de que os infractores, principalmente os adeptos da seita africana, se mostravam dispostos a burlar as determinações contidas na circular do Secretário de Segurança, prohibindo seu funcionamento. Verificou a polícia que os xangôs, depois da referida prohibição, passaram a funcionar em sedes diferentes e a altas horas da noite, sem o característico toque dos tambores [...]". In: FECHADOS PELA POLÍCIA VÁRIOS XANGÔS. Diário de Pernambuco, Recife, 13 de fev. 1938, p. 7.
} 
A partir dos meios e saberes construídos, os xangôs resistiam, surpreendendo em certas situações pelas reações criativas. "Muitas vezes, [...] é entre aqueles que estão mais destituídos dos seus recursos materiais que aparecem formas as mais vigorosas de apego a identidades territoriais" (HAESBAERT, 2007, p. 23). Em 21 de março de 1938, a Folha da Manhã estampava a prisão do pai Antônio Pereira da Silva. Quando preso forjou "incorporar uma entidade", buscando amedrontar os policiais e executar sua fuga pelo telhado da delegacia. ${ }^{23}$ Desprotegidos dos seus terreiros, os negros reinventavam-se em suas resistências. Alguns tratavam de modo agressivo seus opositores, restringindo o acesso ao terreiro. Pai Adão era conhecido pela personalidade forte e arrogância. Todavia, deixava transparecer gentileza em cumprimentos, quando atendia aos interesses de seus filhos de santo. Mesmo após sua morte, a porta do seu xangô era bloqueada por bancos. Inibia-se a entrada a estranhos (FERNANDES, 1937), construindo "níveis distintos de acesso ao território", conforme assertiva de Sack (1986).

Os "catimbolados" criaram de modo contínuo suas estratégias de sobrevivência. Os mecanismos reguladores do Estado, da Igreja, dos kardecistas e jornalistas, ao tentarem extirpar os xangôs, acabaram por sustentar sua manutenção. Se no plano político e econômico um grupo social se impõe aos demais, o mesmo não ocorre na dimensão cultural, onde há a circulação de influências recíprocas entre grupos hegemônicos e subalternos (GINZBURG, 1987). Malgrado as coações, os xangôs conseguiram driblar o poder estabelecido, elaborando estratégias miúdas para manutenção de seus territórios de fé. Michel De Certeau (2005) afirma existir mil modos de jogar/desfazer o jogo do outro, o poder e a ordem imposto por outros. Nestes casos, certos grupos de menor domínio constroem redes de forças e estratégias marcadas por atividades sutis, tenazes e resistentes. Na Catimbolândia, as táticas criadas revestiam-se de identidades territoriais, geossimbolismos negros nos arredores do rio Beberibe, centrados na manutenção da crença e na preservação da memória dos grupos.

À experiência de luta das nações juntaram-se instituições lúdicas, como maracatus, caboclinhos, calungas, clubes de frevo.... Durante a expansão do Recife, várias destas agremiações deslocaram-se dos bairros centrais para os arredores, seguindo o mesmo caminho dos xangôs. Os laços de parentesco e compadrio com os terreiros aproximaram os folguedos aos arredores do Beberibe, multiplicando-se com a chegada mais acelerada de migrantes durante as décadas de 1930-40. Nesta geografia, construíram redes de ajuda mútua, solidarizando-se na estruturação de suas casas. No Portão do Gelo, Mãe Biu ampliara seu terreiro com a construção do "Mexidinho", chegando a alugar quartos para indivíduos externos (COSTA, 2009). A carência de moradia no Recife, ligada ao interesse de novos ganhos, estimulara essa abertura. Em alguns casos, os rotativos criaram vínculos, integrando-se aos xangôs na luta por sua religião e melhores condições de vida. Por outro lado, alguns filhos de santo deixaram os terreiros e foram residir em vilas, com sua religiosidade

${ }^{23}$ In: UM ESPÍRITO RUIM NO CORPO DO CATIMBOZEIRO PEREIRA. Folha da Manhã. Recife. 21 mar. 1938. p. 1. Edição das 16 horas. 
exercitada às escondidas. Outros devem ter mudado de crença, negando sua herança cultural em busca de um direito nunca alcançado em definitivo.

Figura 4. Mãe Joana Baptista no Irokô, em 1947, Sítio de Pai Adão.

$\mathrm{Na}$ imagem de Verger observa-se a mãe de terreiro vestida de branco a realizar suas oferendas ao pé da árvore, a mesma onde ela escondia os orixás da casa quando das invasões da polícia durante a repressão do Estado Novo. Foto Pierre Verger. Xango Joana, Recife, Brasil (1947) - marca d'água exigida.

Fonte: Foto Pierre Verger@Fundação Pierre Verger. Tombo 35916.

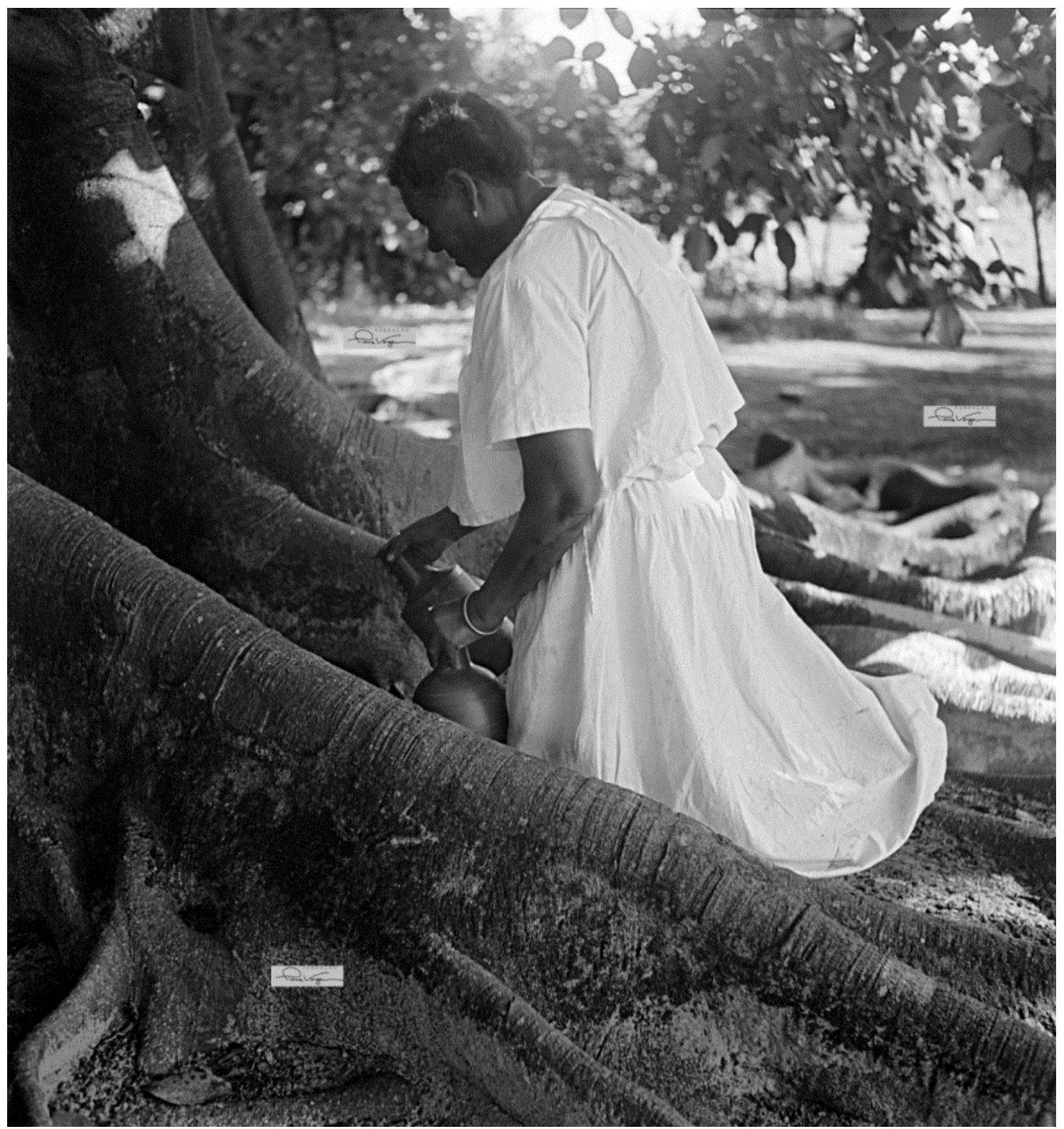

À experiência de luta das nações juntaram-se instituições lúdicas, como maracatus, caboclinhos, calungas, clubes de frevo.... Durante a expansão do Recife, várias destas agremiações deslocaram-se dos bairros centrais para os arredores, seguindo o mesmo caminho dos xangôs. Os laços de parentesco e 
compadrio com os terreiros aproximaram os folguedos aos arredores do Beberibe, multiplicando-se com a chegada mais acelerada de migrantes durante as décadas de 1930-40. Nesta geografia, construíram redes de ajuda mútua, solidarizando-se na estruturação de suas casas. No Portão do Gelo, Mãe Biu ampliara seu terreiro com a construção do "Mexidinho", chegando a alugar quartos para indivíduos externos (COSTA, 2009). A carência de moradia no Recife, ligada ao interesse de novos ganhos, estimulara essa abertura. Em alguns casos, os rotativos criaram vínculos, integrando-se aos xangôs na luta por sua religião e melhores condições de vida. Por outro lado, alguns filhos de santo deixaram os terreiros e foram residir em vilas, com sua religiosidade exercitada às escondidas. Outros devem ter mudado de crença, negando sua herança cultural em busca de um direito nunca alcançado em definitivo.

Em 1945, com a queda de Getúlio Vargas e a vitória dos países Aliados na Segunda Guerra Mundial, a sustentação do regime autoritário passou a ser contestada. Desde 1942, iniciava-se o desmonte do Estado Novo, com o Brasil envolvendo-se na guerra a favor dos Aliados, rompendo com a Alemanha nazista, de Hitler. Com o fim do conflito e do regime varguista, assegurou-se a redemocratização pela Constituição de 1946, garantindo a liberdade de culto. Todavia, alguns setores da sociedade continuaram a discriminar as religiões afro-brasileiras, recrudescendo novas estratégias de resistência entre os filhos de santo. A Federação dos Cultos Afro-Brasileiros trabalhara neste sentido, engendrando outras relações de poder sobre os xangôs quanto à legitimação de sua religiosidade. De modo geral, configuraram-se relações menos violentas quando comparadas ao período estadonovista.

\section{CONSIDERAÇÕES FINAIS}

Na Catimbolândia, os xangôs assentavam-se em laços consanguíneos e em relações de vizinhança e compadrio. No confronto com a Cidade-Veneza, circulavam-se saberes, poderes e culturas, com as territorialidades e geossimbolismos negros recriando-se a todo instante. A religião estruturara-se como instituição, controlando pessoas e dotando de significados objetos e espaços. O cerne desta religiosidade refugiava-se nos xangôs, constituindo-se enclaves demarcados por objetos sagrados- habitados imaterialmente por divindades (orixás) e ancestrais africanos (eguns), e por construções profanas - espaços de lazer e moradia dos filhos de santo. As práticas religiosas, festivas e tradicionais eram exercitadas no terreiro e nos espaços públicos, sobretudo no período noturno, resistindo às imposições de classes dominantes a partir de suas experiências e territórios sacralizados - rios, matagais, rochedos, encruzilhadas e árvores.

Se a territorialidade configura "uma expressão geográfica de poder social", o "meio pelo qual espaço e sociedade estão inter-relacionados" (SACK, 2011, p. 63), os xangôs utilizavam-se desta estratégia como meio de inserção territorial, protegendo-se em suas famílias a partir de suas heranças e saberes. Neste processo 
contribuíram para formação dos bairros do Arruda, Campo Grande, Água Fria, Fundão, Encruzilhada, Mangabeira, e Beberibe, com a Catimbolândia tornando-se um espaço imerso no tecido da cidade, perdendo seus traços de arredores-esconderijos cercados por tufos de matas, morros, alagados e mangues. Contudo, alguns xangôs permaneceram como enclaves de vivência e fé, resistindo em suas apropriações e estratégias, inclusive nos espaços públicos, lócus também de suas memórias e das mais diversas manifestações negras.

\section{REFERÊNCIAS}

ALMEIDA, Maria das Graças Andrade A. de. A construção da verdade autoritária. São Paulo: Humanitas, 2001.

BONNENMAISON, Jöel. Viagem em torno do território. In: CORRÊA, Roberto Lobato; ROSENDAHL, Zeny (Orgs.). Geografia Cultural uma antologia. Rio de Janeiro: EdUERJ, p. 279-304, 2012.

BROWN, Diana. Umbanda Religion and Politics in Urban Brasil. Michigan: Um Research Press, 1986.

CAMPOS, Zuleica Dantas Pereira. 0 combate ao catimbó: práticas repressivas às religiões afroumbandistas nos anos trinta e quarenta. Tese (Doutorado em História) - Universidade Federal de Pernambuco, Recife, 2001.

CAMPOS, Zuleica Dantas Pereira. Perseguida por Agamenon Magalhães: marcas de memória de uma mãede-santo pernambucana. In: Revista SymposiuM. Ano 3, Número Especial, dez., p. 65-70, 1999.

CAPELATO, Maria Helena Rolim. Multidões em cena: propaganda política no varguismo e no peronismo. Campinas: Papirus, 1998.

CARONE, Edgard. O Estado Novo (1937-1945). São Paulo: DIFEL, 1977.

CASTRO, Josué de. Documentário do Nordeste. São Paulo: Brasiliense, 1968.

CERTEAU, Michel De. A invenção do cotidiano. Rio de Janeiro: Ed. Vozes, 2005.

CHALHOUB, Sidney. Visões da liberdade: uma história das últimas décadas da escravidão na corte. São Paulo: Companhia das Letras, 1998.

COSTA, Valéria Gomes. É do Dendê! História e memórias urbanas da Nação Xambá no Recife (1950-1992). São Paulo: Annablume, 2009.

FERNANDES, Gonçalves. Xangôs do Nordeste: investigações sobre os cultos negrofetichistas do Recife. Rio de Janeiro: Civilização Brasileira, 1937.

FREYRE, Gilberto. Guia prático, histórico e sentimental da cidade do Recife. Rio de Janeiro: José Olympio Editôra, 1968.

GINZBURG, Carlo. O Queijo e os Vermes: o cotidiano e as ideias de um moleiro perseguido pela Inquisição. São Paulo: Companhia das Letras, 1987.

GOMINHO, Zélia de Oliveira. Veneza Americana X Mucambópolis - o Estado Novo na cidade do Recife (Décadas de 30 e 40 ). Dissertação (Mestrado em História) - Centro de Filosofia e Ciências Humanas, Universidade Federal de Pernambuco, Recife, 1997.

GUERRA, Lúcia Helena Barbosa. Xangô rezado baixo. Xambá tocando alto: a reprodução da tradição religiosa através da música. Dissertação (Mestrado em História) - Centro de Filosofia e Ciências Humanas, Universidade Federal de Pernambuco, Recife, 2010.

GUILLEN, Isabel. Catimbó: saberes e práticas em circulação no Nordeste dos anos 1930-1940. In: ; LIMA, Ivaldo Marciano de França. Cultura afro-descendente no Recife: Maracatus, Valentes e Catimbós. Recife: Edições Bagaço, p. 203-230, 2007.

FOUCAULT, Michel. Microfísica do Poder. 11 Ed. Rio de Janeiro: Graal, 1993.

HAESBAERT, Rogério. Território e territorialidade - um debate. In: Geographia (UFF), Rio de Janeiro, Vol. 9, n. 17, p. 19-46, 2007.

HALLEY, Bruno Maia. Catimbolândia: tramas negras do xangô na Veneza Americana - os arredores do rio Beberibe (Recife, 18671945). 2017. Tese (Doutorado em Geografia) - Instituto de Geociências, Universidade Federal Fluminense, 2017.

LIMA, Vicente. Xangôs. Recife: Empresa do Jornal do Commércio, 1937. 
LUSTOSA, Oscar. A Igreja Católica no Brasil República. São Paulo: Ed. Paulinas, 1991.

MELO, Mário Lacerda de. Pernambuco: traços de geografia humana. Recife: Gráfica Jornal do Commércio, 1940.

MUSEU DO ESTADO DE PERNAMBUCO. Coleção culto afro-brasileiro - um testemunho do xangô pernambucano. Recife, 1983.

QUEIROZ, Martha Rosa. Religiões afro-brasileiras no Recife: intelectuais, policiais e repressão. Dissertação (Mestrado em História) Centro de Filosofia e Ciências Humanas, Universidade Federal de Pernambuco, Recife, 1999.

RAFFESTIN, Claude. Por uma Geografia do Poder. São Paulo: Ática, 1993.

RIBEIRO, Antônio Chagas. Mocambos... Romance. Recife: Edições Mozart, 1936.

SACK, Robert. Human territoriality: its theory and history. Cambridge: Cambridge University Press, 1986.

VALENTE, Waldemar. Sincretismo religioso Afro-brasileiro. São Paulo: Nacional, 1955.

\section{JORNAIS CONSULTADOS}

A “MACUMBA" A SERVIÇO DO FUTEBOL. Folha da Manhã. Recife, 31 de julho. 1944, p. 4. Edição Matutina.

AS ABERRAÇÕES DA CRENDICE POPULAR. Jornal do Pequeno. Recife: 20 de agosto de 1931.

BANDEIRA DO SÍTIO. Roberto Benjamin. Jornal da Cidade. Recife. 03 a 09 de junho de 1976.

CAHIU DO “ALTAR" O ULTIMO “ORIXÁ”. Folha da Manhã. Recife, 15 abr. 1939. p. 8. Edição das 16 horas.

CAMPANHA CONTRA CATIMBOZEIROS. Folha da Manhã. Recife, 09 de julho. 1938. p. 08. Edição Matutina.

CONTRA O BAIXO ESPIRITISMO. Folha da Manhã. Recife, 08 de maio. 1938. p. 08. Edição Matutina.

CONTRA O ESPIRITISMO E A FALSA MEDICINA. Folha da Manhã. Recife, 17 de agosto. 1938. p. 12. Edição Matutina.

EM REPRESÃO AO BAIXO ESPIRITISMO. Uma visita da polícia ao “Centro dos Reis Magos”. O Fechamento do Círculo Pantheísta. Diário da Tarde. Recife, 08 de fevereiro de 1938.

FECHADOS PELA POLÍCIA VÁRIOS XANGÔS. Diário de Pernambuco. Recife, 13 de fev. 1938, p. 7.

O CENTRO ESPÍRITA CARIDADE E AMOR EM JESUS CRISTO TRANSFORMADO EM SÊDE DE “MACUMBAS” DESENFREADAS E DELIRANTES - AS EXTRANHAS RECEITAS DOS “ESPÍRITOS” - ETC. Diário da Tarde. Recife, 12 de abril de 1934.

UM ESPÍRITO RUIM NO CORPO DO CATIMBOZEIRO PEREIRA. Folha da Manhã. Recife. 21 mar. 1938. p. 1. Edição das 16 horas. 